\title{
Hydro-priming and halo-priming improve seed germination, yield and yield contributing characters of Okra (Abelmoschus esculentus L.)
}

\author{
Shaila Shermin Tania ${ }^{1}$, Mohammad Saidur Rhaman $^{1}$ and Md. Mokter Hossain ${ }^{2}$ \\ ${ }^{1}$ Department of Seed Science and Technology, Bangladesh Agricultural University, \\ Mymensingh-2202, Bangladesh \\ ${ }^{2}$ Department of Horticulture, Bangladesh Agricultural University, Mymensingh-2202, Bangladesh
}

*Corresponding Author: saidur69bau@gmail.com

[Accepted: 10 March 2020]

\begin{abstract}
Seed priming is a pre-sowing treatment which enables the seed to germinate more efficiently and improves seedling vigor as well as yield. Hydro-priming is an important seed treatment technique for rapid seed germination and pre-sowing of seeds with halo-priming is also known as an effective tool. Therefore, a study was conducted with the aim of evaluating the effect of different priming sources with various durations on okra seeds germination and development. Two varieties of okra viz. BARI Dheros $2\left(\mathrm{~V}_{1}\right)$ and Green finger okra $\left(\mathrm{V}_{2}\right)$ having four treatments ( $\mathrm{T}_{1}$, non-primed seeds; $\mathrm{T}_{2}$, seed soaking with normal tap water $\pm 25^{\circ} \mathrm{C}$ for $12 \mathrm{hr} ; \mathrm{T}_{3}$, priming with hot water $50^{\circ} \mathrm{C}$ for $5 \mathrm{~min}$; $\mathrm{T}_{4}$, priming of seeds with $3 \% \mathrm{NaCl}$ for $12 \mathrm{hr}$ ) were investigated in a completely randomized design (CRD), each treatment being replicated three times. Results of the study showed that maximum seed germination percentage (92.79\%), seed vigor index $(1019 \mathrm{~cm})$, first flowering days, days to harvesting maturity, 1000 seeds weight, and total number of fruits per plant (29.5) were observed when the seeds primed by hot water $50^{\circ} \mathrm{C}$ for $5 \mathrm{~min}$. In this study, seed germination and all other parameters were also increased by normal water and halo-priming (3\% $\mathrm{NaCl}$ ). Our results showed that hydro-priming (with hot water) were found superior to hydropriming (with normal water) and halo-priming $(3 \% \mathrm{NaCl})$. Both priming influenced performance of two varieties, though green finger variety showed slightly better performance in almost all the parameters over the variety BARI Dheros 2. Our results suggest that hydro-priming and halopriming can improve okra seed germination as well as okra production.
\end{abstract}

Keywords: Germination - Seed priming - Yield - Vigour.

[Cite as: Tania SS, Rhaman MS \& Hossain MM (2020) Hydro-priming and halo-priming improve seed germination, yield and yield contributing characters of Okra (Abelmoschus esculentus L.). Tropical Plant Research 7(1): 86-93]

\section{INTRODUCTION}

Okra (Abelmoschus esculentus L.) commonly known as "Dheros" is a popular summer vegetable crop in Bangladesh under the family Malvaceae. It offers a wide range of health benefits. The seed of okra is a source of antioxidants, which is essential in maintaining health. Okra pods are good source of flavonoid antioxidants like beta carotene, xanthine and lutein (Dilruba et al. 2009). Okra flour has huge potential for use to enrich foods in order to provide adequate nutritional daily needs (Adelakun \& Oyelade 2011). Bangladesh produces about $56145 \mathrm{M}$. tons from 11458.70 hectares of land with an average yield of 1.98 tons per hectare (BBS 2017-18). The average price of okra in Dhaka open market is $50.20 \mathrm{t} \mathrm{kg}^{-1}$ (BBS 2018). This cost (relatively high) may be the consequence of insufficient production of okra. Slow germination and poor seedling emergence might be important reason behind insufficient production.

Okra is a warm-season crop. It requires ample moisture for germination. In okra seed, slow and erratic emergence is the main problem which results in low fertilizer efficiency, unsynchronized harvesting and ultimate low yield (Rahman et al. 2016). Due to the hard seededness of okra, the seed germination percentage is 
relatively low (Felipe et al. 2010). Okra seeds did not promptly germinate after planting that was faced by okra farmers in some regions of Bangladesh. It does not germinate below $20^{\circ} \mathrm{C}$ (Sadik et al. 1998). At sub-optimal temperatures, poor seed germination is a common phenomenon and also a great concern of growers that's why in the Mediterranean region farmers grow seedlings in late winter and early spring (Tzortzakis 2009).

Seed priming is a pre-sowing technique in which seed is allowed to imbibe water which make seeds are more capable to hydrate to the point where pre-germinative metabolic activities start without actual germination. Seed priming is known to enhanced velocity and uniformity of seedling emergence and increased seed tolerance to unfavorable environmental conditions (Lima \& Marcos 2010). It involves imbibition of seeds in water under controlled conditions up to the point of radical emergence followed by drying the seed back to its initial moisture content (Ratikanta 2011).

Different seed treatment techniques including priming are used to improve the germination properties of seeds (Badek et al. 2006). Hydro-priming is a very important technique which results in rapid germination, improved seed growth and uniform stand establishment in various crops (Adebisi et al. 2013). Sikhondze \& Ossom (2011) conducted an experiment to determine priming effects on okra seeds and found hydro-priming as beneficial to the seedling growth. A significant improvement in seed germination, seedling emergence, stand establishment, and final crop yield in salt affected soil have been shown from different studies in response to halo-priming (Khan et al. 2009). Findings of Kaur et al. (2015) showed that hydro-priming increases different agronomic characters of okra such as number of days taken to 50\% flowering, seedling growth, fruit length and weight, total yield per plant etc. Hydro-priming improves seed germination, seedling growth, and yield of bitter gourd (Tania et al. 2019). Priming both hydro and halo improved quality parameters of wheat (Singh et al. 2017).

Therefore, a study was carried out to address the problem of okra about poor seed germination and low yield performance, as well as to evaluate the effects of different priming treatments on okra seed germination and yield performance.

\section{MATERIALS AND METHODS}

To assess the effect of seed priming treatments and soaking duration on germination, yield, and yield contributing characters of okra (Abelmoschus esculentus L.) a two factorial experiment was carried out at the laboratory of the department of Seed Science and Technology, Bangladesh Agricultural University, Mymensingh during mid-February to mid-July. The experiment was arranged in a completely randomized design (CRD) with three replication. Priming treatments included $\mathrm{T}_{2}$ (seed soaking with normal tap water \pm $25^{\circ} \mathrm{C}$ for $12 \mathrm{hr}$ ), $\mathrm{T}_{3}$ (priming with hot water $50^{\circ} \mathrm{C}$ for $5 \mathrm{~min}$ ) and $\mathrm{T}_{4}$ (priming of seed with $3 \% \mathrm{NaCl}$ for $12 \mathrm{hr}$ ). Non-primed seeds were considered as control $\mathrm{T}_{1}$. Two varieties of seeds viz. BARI Dheros 2 and Green finger okra (hybrid variety developed by Lal Teer Seed Company) were used in this experiment.

The seeds of two varieties from each treatment were tested for germination by a rolled towel method. The seeds from the selected varieties were dipped into different priming treatments. At the end of each soaking, the seeds were air-dried at room temperature for at least $2 \mathrm{hr}$ to reach the original moisture level. Fifty seeds were taken randomly from each variety and treatment and uniformly placed on the germination paper which was moistened with distilled water. The rolled towels were kept in the seed germination and their constant temperature of $25 \pm 1^{\circ} \mathrm{C}$, 95 percent relative humidity was maintained. The germination percentage was calculated based on the following equation of Anonymous (1999).

$$
\text { Germination percentage }=\frac{\text { Total number of germinated seeds }}{\text { Total number of seeds sown }} \times 100
$$

Shoot length and root length were measured to calculate seed vigor index at the same DAS (Days after sowing) of final counting of germination percentage. Seed vigor index was calculated by multiplying germination percentage $(\%)$ and seedling length in $\mathrm{cm}$ (shoot length + root length). The seed lot showing the higher vigor index is considered to be more vigorous (Abdul \& Anderson 1973). The calculation is as follows:

$$
\text { Seed vigor index }=\text { Germination percentage }(\%) \times \text { Seedling length }(\mathrm{cm})
$$

The remaining representative seedlings were transplanted in the experimental pot. To get healthy and disease free plants, seedling were taken under care and observation. Different reproductive characters like days to flower bud initiation, days to first flowering, harvesting maturity, total no of fruits per plant and finally 1000 seeds weight were recorded from the sample plants.

All data were tabulated and the means for all treatments were calculated. Obtained data from different parameters were statistically analysed by using Minitab 18. Duncan's multiple range test at $5 \%$ level of 
probability was calculated to compare between means, as shown by Dospekhov (1984).

\section{RESULTS AND DISCUSSION}

\section{Germination percentage}

Many studies reported that different seed priming treatments improve seed emergence and performance of okra (Arif et al. 2003, 2008, Pandita et al. 2010). In this study, seed priming treatments showed a significant difference in terms of germination percentage (Table 1). The highest germination percentage $(92.79 \%)$ was found from the $\mathrm{T}_{3}$ (priming with hot water $50^{\circ} \mathrm{C}$ for $5 \mathrm{~min}$ ); whereas non-primed seeds showed lowest germination $(63.49 \%$ ) (Table 1). There was no significant difference in between two varieties of okra seeds in respect of seed germination (Table 2). However, in their interaction, the highest germination was recorded $(93.11 \%)$ when the seeds were drenched in hot water and the lowest seed germination was recorded $(61.79 \%)$ from non-primed seeds (Fig. 1A). These results indicate that seed priming with different treatments improved the germination percentage of seeds as compared with non-primed control seeds. It is well known that different priming sources and durations affect germination percentage because seeds of each species need a specific amount of water to get into the lag phase of germination in which all the pre-germinative metabolic processes occurs (Rahman et al. 2016). So, if priming is done for a short period then seed would not get enough water that is required for getting seed into the lag phase of germination. On the other hand, prolong period of priming will allow excess of water that may exceed the quantity required for the initiation of lag phase of germination and radicle protrusion will occur due to which seed loses its desiccation tolerance thereby results in loss of seed viability (Pereira et al. 2014, Dekkers et al. 2015). When seeds are treated with water and salt solution it helps to absorb water easily but when seeds are treated with hot water, it helps to remove some surface pathogens of seeds (Nega et al. 2003) and also better activation of enzymes which may induce germination.

Table 1. Effects of different priming agents on seed germination, seed vigor index, flower bud initiation, first flowering, harvesting maturity, total no of fruits/plant, and 1000 seeds weight of okra.

\begin{tabular}{rrrrrrrr}
\hline Treatment Germination & $\begin{array}{r}\text { Seed vigor } \\
\text { percentage } \\
\text { index }(\mathbf{C m})\end{array}$ & $\begin{array}{r}\text { Days to flower } \\
\text { bud initiation } \\
\text { (DAS) }\end{array}$ & $\begin{array}{r}\text { Days to first } \\
\text { flowering } \\
\text { (DAS) }\end{array}$ & $\begin{array}{r}\text { Days to } \\
\text { maturity (DAS) }\end{array}$ & $\begin{array}{r}\text { Total no. of 1000 seeds } \\
\text { fruits/plant }\end{array}$ & $\begin{array}{r}\text { weight } \\
(\mathbf{g})\end{array}$ \\
\hline $\mathrm{T}_{1}$ & $63.5 \mathrm{~d}$ & $654.33 \mathrm{~d}$ & $24 \mathrm{a}$ & $30.83 \mathrm{a}$ & $40.33 \mathrm{a}$ & $23.17 \mathrm{c}$ & $58.23 \mathrm{c}$ \\
$\mathrm{T}_{2}$ & $84.4 \mathrm{~b}$ & $748.17 \mathrm{c}$ & $21.5 \mathrm{c}$ & $26.83 \mathrm{c}$ & $35.83 \mathrm{~b}$ & $26.67 \mathrm{~b}$ & $72.52 \mathrm{a}$ \\
$\mathrm{T}_{3}$ & $92.79 \mathrm{a}$ & $1019 \mathrm{a}$ & $21.67 \mathrm{c}$ & $26.67 \mathrm{c}$ & $34 \mathrm{c}$ & $29.5 \mathrm{a}$ & $73.44 \mathrm{a}$ \\
$\mathrm{T}_{4}$ & $72.15 \mathrm{c}$ & $767.17 \mathrm{~b}$ & $22.67 \mathrm{~b}$ & $28.17 \mathrm{~b}$ & $36 \mathrm{~b}$ & $26.5 \mathrm{~b}$ & $69.35 \mathrm{~b}$ \\
\hline
\end{tabular}

Note: Means with the same letters in a column are not significant at $5 \%$ level.

Table 2. Varietal effects on seed germination, seed vigor index, flower bud initiation, first flowering, harvesting maturity, total no of fruits/plant and 1000 seeds weight of okra.

\begin{tabular}{rrrrrrrr}
\hline Variety & $\begin{array}{r}\text { Germination } \\
\text { percentage } \\
(\%)\end{array}$ & $\begin{array}{r}\text { Seed vigor } \\
\text { index } \\
(\mathbf{c m})\end{array}$ & $\begin{array}{r}\text { Days to flower } \\
\text { bud initiation } \\
\text { (DAS) }\end{array}$ & $\begin{array}{r}\text { Days to first } \\
\text { flowering } \\
\text { (DAS) }\end{array}$ & $\begin{array}{r}\text { Days to } \\
\text { maturity (DAS) }\end{array}$ & $\begin{array}{r}\text { Total no of } \\
\text { fruits/plant }\end{array}$ & $\begin{array}{r}\text { 1000 seeds } \\
\text { weight } \\
(\text { g) }\end{array}$ \\
\hline $\mathrm{V}_{1}$ & $77.70 \mathrm{a}$ & $791.33 \mathrm{~b}$ & $22.58 \mathrm{a}$ & $28.33 \mathrm{a}$ & $36.5 \mathrm{a}$ & $26.33 \mathrm{a}$ & $66.7 \mathrm{~b}$ \\
$\mathrm{~V}_{2}$ & $78.70 \mathrm{a}$ & $803 \mathrm{a}$ & $22.33 \mathrm{a}$ & $27.92 \mathrm{a}$ & $36.58 \mathrm{a}$ & $26.58 \mathrm{a}$ & $70.0 \mathrm{a}$ \\
\hline
\end{tabular}

Note: Means with the same letters in a column are not significant at $5 \%$ level.

\section{Seed vigor index}

Our results showed that the treated seeds significantly increased the seed vigor index compared to control (Table 1). Maximum seedling vigor index as recorded in $\mathrm{T}_{3}(1019 \mathrm{~cm})$ followed by $\mathrm{T}_{4}(767.17 \mathrm{~cm}), \mathrm{T}_{2}(748.17$ $\mathrm{cm}$ ) and it was minimum in un-primed seeds (Table 1). Priming treatments not only showed a significant effect on seed vigor index but also in varietal performance. Green finger okra seeds resulted $803 \mathrm{~cm}$ seed vigor index which was significant with the obtained value $(791.33 \mathrm{~cm}$ ) from BARI Dheros 2 (Table 2). In the interaction of variety and treatment, highest seedling vigor index was recorded $1023 \mathrm{~cm}$ and lowest vigor index was $649 \mathrm{~cm}$ (Fig. 1B).

These results resemblance with the previous findings (Kaur et al. 2015). Faster germination, uniform seedling emergence (Halmer et al. 2004) and increased shoot length and root length of seedlings observed in primed seed might be due to the induction of different metabolic activities in the seed embryo (Wahid et al. 2008). Seedling vigour index of germinating seeds have profound influence on the establishment and yield of crops (Tabrizian \& Osareh 2007). Optimum plant establishment of maize can ensure in the field by maintaining proper hydro-prime duration (Mahmoodi et al. 2011). Vigorous plant could be produced from rapid emergence of seedlings (Ghassemi-Golezani et al. 2008). Taken all results together, we can say that hydro-and halopriming improve seed vigour and helps to establish profound stand. 

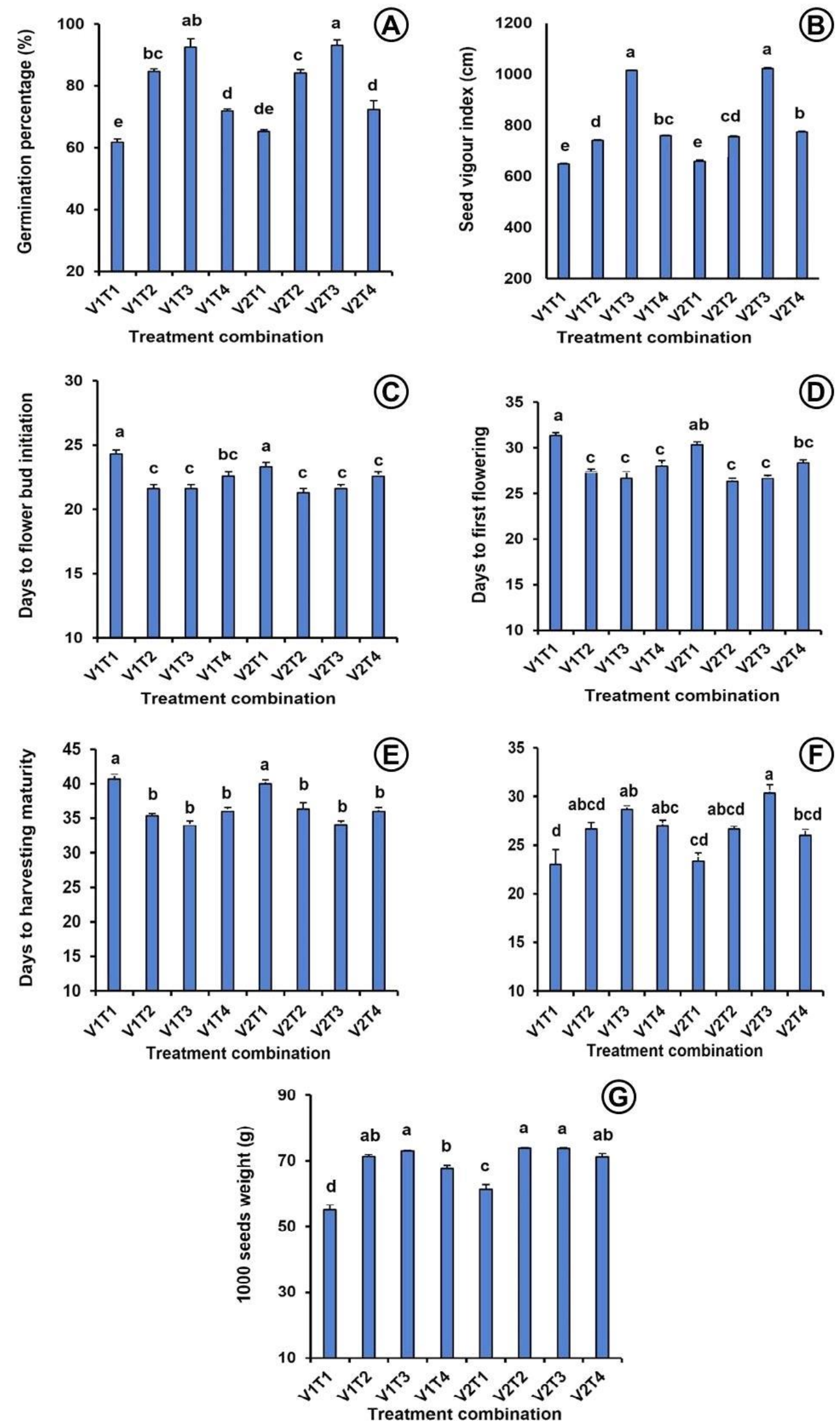

Figure 1. Combined effects of treatments and variety on seed germination, yield, and yield contributing characters of okra: A, Effects on seed germination; B, Effects on seed vigour index; C, Effects on flower bud initiation; D, Effects on days to first flowering; E, Effects on days to harvesting maturity; F, Effects on total no of fruits/plants; G, Effects on 1000 seeds weight. [Error bar represents standard error. Means with the same letters in a figure are not significant at $5 \%$ level] 


\section{Flower bud initiation}

There was a significant difference observed in flower bud initiation among the treatments. It was found that seeds priming with hot water $50^{\circ} \mathrm{C}$ for $5 \mathrm{~min}$ and normal water $\pm 25^{\circ} \mathrm{C}$ for $12 \mathrm{hr}$ produce first flower bud only at 21.67 and 21.50 DAS respectively (Table 1). On the other hand, seeds without priming needed maximum days for the first initiation of flower bud and it was 24 DAS (Table 1). Priming treatments did not show any significant difference on flower bud initiation in varietal performance (Table 2). Similarly, in the interaction of variety and treatment, there was no significant difference among the treatments on flower bud initiation but there was a significant difference with control (Fig. 1C). The earliness of flower bud formation due to priming may be ascribed to ease the uptake of nutrients and simultaneously transport of growth-promoting substances like cytokinin to the axillary buds resulting in breakage of apical dominance (Yadav et al. 2009). These results suggest that hydro-priming and halo-priming improves initiation of flower bud by making easier of nutrient uptake as several studies previously shown that hot water and salt helps to absorb water and nutrient easily.

\section{Days to first flowering}

These findings evolved that non-primed seeds gave flowering later whereas treated seeds gave flowering earlier compared with the non-primed. Treatment $\mathrm{T}_{3}$ and $\mathrm{T}_{2}$ required 26.67 DAS and 26.83 DAS to first flowering followed by $\mathrm{T}_{4}(28.17 \mathrm{DAS})$. Maximum days to flowering (30.83 DAS) were recorded for control (Table 1). For the required days to first flowering, two varieties showed non-significant variation (Table 2). In the interaction of variety and treatment, it was statistically similar among the treatments on days to first flowering but there was a significant difference with control (Fig. 1D). These results are in line with the findings of Negi (2009) who observed early flowering, the number of flowers/plant and flower size incarnation cuttings treated with T. viride. Burgass \& Powell (1984) reported that seed priming can reduce flowering days over unprimed seeds. Taken together these results suggest that hydro-priming and halo-priming reduce flowering days in okra.

\section{Days to harvesting maturity of fruits}

Significant gaps were remarked in days to harvesting maturity because of different priming treatments. Seeds primed at hot water significantly reduced days to harvesting maturity as compared to other treatments and un-primed seeds (Table 1). This may be due to early emergence of seeds by priming. There was no significant variation between $\mathrm{T}_{2}$ (35.86 DAS) and $\mathrm{T}_{4}$ (36 DAS), whereas non-primed seeds took the highest time 40.33 days to reach harvesting maturity compared to other primed seed (Table 1). There was no significant difference on days to harvesting maturity in varietal performance (Table 2). However, in the interaction of variety and treatment statistically non-significant differences found among the treatments but there was a significant difference with control (Fig. 1E). Overall, all treated seeds took 34 to 36 days to first pod harvest and seeds from without priming required 40 days to be mature for harvesting. Our results agree with Murungu et al. (2004). Barlow \& Haigh (1986) who reported that priming reduces days to flowering and edible maturity.

\section{Number of total fruits/plant}

The mean values of the data showed that priming treatments significantly affected yield (Table 1), though their varietal competency was found non-significant (Table 2). Our data showed that the seeds primed with normal tap water to hot water had a significant increase occurred whereas, hydro-priming with hot water gave maximum numbers fruits per plant (29.5) as compared with the control (23.1). In this respect, seeds drenched with normal tap water $\pm 25^{\circ} \mathrm{C}$ and $3 \% \mathrm{NaCl}$ salt solution gave the second higher no of fruits (26.67 and 26.5) (Table 1). Results obtained in figure $1 \mathrm{~F}$, demonstrated that there was significant differences in the fruit numbers per plant under the influence of priming treatments. Effects of hydro- (with normal water) and halo-priming on fruit/plant indicated statistically non-significant but were significant over control.

As yield is the final objective and is a function of multiple factors it is obviously affected from the activities from sowing to harvest. Seed priming with hot water significantly enhanced final yield in okra crop. Primed seeds with hot water had generally encouraged smooth germination over non-primed and other treatments due to which more yield was obtained from plants raised from hot water primed seeds. Mohammadi (2009) had also reported that priming caused an increase in yield. The difference between primed and unprimed seeds in case of no. of fruits/plant was two or five which may not be important to small farmers but obviously be a big difference for commercial farmers. Several studies reported that seed priming enhance plant vigor and subsequently its yield. Thus, primed okra seeds improved yield (Rahman et al. 2016). In addition, priming of red bean seeds significantly affected plant dry matter, grain yield, 100-grain weight and number of pods (Rastin et al. 2013). Taken together these results, it is suggested that hydro-priming and halo-priming can improves the yield of okra. 
1000 seeds weight

Statistical analysis of the data indicated that 1000 seeds weight was significantly varied with priming agents. The maximum 1000-seed weight (73.44 g) was observed in seed priming with hot water which was not significantly different from seed priming of normal water $(72.52 \mathrm{~g})$. The second highest value of 1000 seeds weight was observed $69.35 \mathrm{~g}$ for treatment $\mathrm{T}_{4}$ (Table 1). In the comparison of varietal effects, green finger okra showed heaviest seed weight over the BARI Dherosh-2 (Table 2). In the interaction of variety and treatment, the highest thousand seeds weight $\left(73.81 \mathrm{~g}\right.$ ) was recorded from treatment $\mathrm{T}_{2}$ with the combination of variety green finger whereas lowest value $(55.05 \mathrm{~g})$ was recorded for the interaction of control with BARI Dheros 2 (Fig. 1G). These results are consistent with the findings of (Ashby et al. 1936). These results also support the findings of Basra et al. (2003) who reported greater 1000-grain weight for primed seed and observed greater amount of dry matter accumulation for priming treatments. A similar variation was observed by Saifullah et al. (2009) where weight of 100 seeds ranged from 5.50 to $8.25 \mathrm{~g}$. The 1000 seed weight is strongly affected by genetics and environmental factors and its amount is affected by the condition of maturity period, these conditions may leads to $20-30 \%$ changes in 1000-seed weight and the higher potential of 1000 -seed weight it might due to the initial capacity and more amount of nutrients available for germination (Sankar \& Mani 2015).

\section{CONCLUSION}

From the findings of this research work, it was found that hydro- and halo-priming improve the growth and yield parameters of okra. Moreover, green finger okra variety showed slightly better performance than the variety BARI Dheros 2. Our results conclude that slow germination problems and maximization of okra production can be improved by hydro- and halo-priming.

\section{REFERENCES}

Abdul AA \& Anderson JD (1973) Vigour determination in soybean by multiple criteria. Crop Science 13: 630633.

Adebisi MA, Kehinde TO, Abdul-Rafiu MA, Esuruoso OA, Oni OD \& Ativie O (2013) Seed physiological quality of three Capsicum species as affected by seed density and hydropriming treatment durations. Journal of Agronomy 12: 38-45.

Adelakun OE \& Oyelade OJ (2011) Potential Use of Okra Seed (Abelmoschus esculentus Moench) Flour for Food Fortification and Effects of Processing. In: Flour and breads and their fortification in health and disease prevention. Academic Press, 205-212p.

Anonymous (1999) International rules for seed testing. Seed Science and Technology 27: 25-30.

Arif M, Kakar KM \& Yunas M (2003) Seed soaking enhances emergence of mungbean. Sarhad Journal of Agriculture 19: 439-441.

Arif M, Jan MT, Marwat BK \& Khan MA (2008) Seed priming improves emergence and yield of soybean. Pakistan Journal of Botany 40(3): 1169-1177.

Ashby E (1936) Initial Capital Theory. Annals of Botany 16: 1006-1032.

Badek B, Duijn B van \& Grzesik M (2006) Effects of water supply methods and seed moisture content on germination of China aster (Callistephus chinensis) and tomato (Lycopersicon esculentun Mill.) seeds. European Journal of Agronomy 24 (1): 45-51.

Barlow EWR \& Haigh AM (1986) Effect of seed priming on the emergence, growth and yield of UC 82B tomatoes in the field. In: II International Symposium on Processing Tomatoes XXII (IHC 200), 153-164.

Basra SMA, E Ullah EA, Warriach MA, Cheema \& Afzal I (2003) Effect of storage on growth and yield of primed canola seeds (Brassica napus L.). International Journal of Agricultural and Biology 5: 117-120.

BBS (2017-18) Summary Crop Statistics. Bangladesh Bureau of Statistics, Statistical Division, Ministry of Planning, Government People's Republic of Bangladesh, Dhaka, Bangladesh, 6 p.

BBS (2018) Consumer Price Index (CPI), Inflation Rate and Wage Rate Index (WRI) in Bangladesh. Bangladesh Bureau of Statistics, Statistical Division, Ministry of Planning, Government People's Republic of Bangladesh, Dhaka, Bangladesh, $19 \mathrm{p}$.

Burgass WR \& Powell AA (1984) Evidence for repair processes in the invigoration of seeds by hydration. Annals of Botany 53: 753-757

Dekkers BJ, Costa MCD, Maia J, Bentsink L, Ligterink W \& Hilhorst HW (2015) Acquisition and loss of desiccation tolerance in seeds: From experimental model to biological relevance. Planta 241(3): 563-577.

Dilruba S, Hasanuzzaman M, Karim R, \& Nahar K (2009) Yield response of okra to different sowing time and application of growth hormones. Journal of Horticultural Science 1: 10-14.

www.tropicalplantresearch.com 
Dospekhov PA (1984) Field Experimentations and Statistical Procedures. Mir Publishers Moscow.

Felipe VP, Antonio AL, \& Francisco AP (2010) Improvement of Okra (Abelmoschus esculentus L.) Hardseedness by using microelements Fertilizer. Journal Horticultura Brasileira 28: 232-235.

Ghassemi-Golezani K, Sheikhzadeh-Mosaddegh P, \& Valizadeh M (2008) Effects of hydro-priming duration and limited irrigation on field performance of chickpea. Research Journal of Seed Science 1: 34-40.

Halmer P (2004) Methods to improve seed performance in the field. In: Benech-Arnold RL \& Sanchez RA (eds) Handbook of Seed Physiology, Application to Agriculture. The Haworth Press, New York, pp. 125-165.

Kaur H, Chawla N \& Pathak M (2015) Effect of different seed priming treatments and priming duration on biochemical parameters and agronomic characters of okra (Abelmoschus esculentus L.). International Journal of Plant Physiology and Biochemistry 7(1): 1-11.

Khan HA, Ayub CM, Pervez MA, Bilal RM, Shahid MA \& Ziaf K (2009) Effect of seed priming with NaCl on salinity tolerance of hot pepper (Capsicum annuum L.) at seedling stage. Soil Environment 28: 81-87.

Lima LB de \& Marcos FJ (2010) Cucumber (Cucumis sativus) seed priming methods and germination at different temperatures. Revista Brasileira de Sementes 32(1): 138-147.

Mahmoodi TM, Ghassemi-Golezani K, Habibi D, Paknezhad F \& Ardekani MR (2011) Effect of hydro-priming duration on seedling vigour and field establishment of maize (Zea mays L.). Research on Crops 12(2): 341345.

Mohammadi GR (2009) The effect of seed priming on plant traits of late-spring seeded soybean. AmericanEurasian Journal of Agricultural and Environmental Science 5(3): 322-326.

Murungu FS, Chiduza C, Nyamugafata P, Clark LJ \& Whalley WR (2004) Effect of on-farm seed priming on emergence, growth and yield of cotton and maize in a semi-arid area of Zimbabwe. Experimental agriculture 40(01): 23-36.

Nega E, Ulrich R, Werner S \& Jahn M (2003) Hot water treatment of vegetable seed - an alternative seed treatment method to control seed-borne pathogens in organic farming. Journal of Plant Diseases and Protection 1: 220-234.

Negi HS (2009) Integrated management of wilt of carnation caused by Fusarium oxysporum f sp. dianthi (Prill. and Del.), (Master' Thesis). University of Horticulture and Forestry, Solan.

Pandita VK, Anand A, Nagarajan S, Seth R \& Sinha SN (2010) Solid matrix priming improves seed emergence and crop performance in okra. Plant Physiology 38: 665-674.

Pereira WVS, JMR Faria, Tonetti OAO \& Silva EAA (2014) Loss of desiccation tolerance in Copaifera langsdorffii Desf. Seeds during germination. Brazilian Journal of Biology 74(2): 501-508.

Rahman I, Ali S, Adnan M, Ibrahim M, Saleem N, \& Khan IA (2016) Effect of seed priming on growth parameters of Okra (Abelmoschus esculentus L.). Pure and Applied Biology 5(1): 165.

Rastin S, Madani H \& Shoaei S (2013) Effect of seed priming on red bean (Phaseolus calcaratus) growth and yield. Annals of Biological Research 4(2): 292-296.

Ratikanta KM (2011) Seed priming: an efficient farmers' technology to improve seedling vigour, seedling establishment and crop productivity. International Journal of Bio-resource Stress Management 2(3): 1-4.

Sadik W, Amin M \& Shahzoor NU (1998) Performance of okra cultivars under soil and climatic condition of Peshawar. Sarhad Journal of Agriculture 4: 633-638.

Saifullah M \& Rabbani MG (2009) Evaluation and characterization of okra [Abelmoschus esculentus (L.) Moench] genotypes. SAARC Journal of Agriculture 7(1): 92-99.

Sankar YS \& Mani A (2015) Studies on Seed Quality Parameters of Okra (Abelmoschus esculentus L.). Journal of Agriculture and Technology 2(2): 79-83.

Sikhondze DK \& Ossom EM (2011) Impact of priming okra (Abelmoschus esculentus L.) seeds on seedling performance in Swaziland. Advances in Environment Biology 5: 1221-1228.

Singh BA, Gangwar CS, Singh P \& Maurya CL (2017) Effect of seed priming on quality parameters of wheat (Triticum aestivum L.) seeds harvested under irrigated \& rainfed conditions. Journal of Pharmacognosy and Phytochemistry 6(4): 1646-1650.

Tabrizian F \& Osareh AM (2007) Improved seed emergence and yield related traits of marigold (Calendula officinalis L.) by on-farm seed micronutrient treatment trials. Journal of Crop Science 9: 124-141.

Tania SS, Hossain MM \& Hossain MA (2019) Effects of hydropriming on seed germination, seedling growth and yield of bitter gourd. Journal of Bangladesh Agricultural University 17(3): 281-287.

Tzortzakis GN (2009) Effect of pre-sowing treatment on seed germination and seedling vigour in endive and chicory. Horticultural Science 36(3): 117-125. 
Wahid A, Noreen A, Basra SMA, Gelani S \& Farooq M (2008) Priming-induced metabolic changes in sunflower (Helianthus annuus) achenes improve germination and seedling growth. Botanical Studies 49: 343-350.

Yadav RL, Shukla SK, Suman P \& Singh PN (2009) Trichoderma inoculation and trash management effects on soil microbial biomass, soil respiration, nutrient uptake and yield of ratoon sugarcane under subtropical conditions. Biology and Fertility of Soils 45: 461-468. 